\title{
Microbial communities and activities in caves
}

\section{Ramat Onyeneoyiza Raji*, Oluwafemi Adebayo Oyewole, Omeiza Haruna Ibrahim, Yetunde Noimot Tijani and Mordecai Gana}

Department of Microbiology. Federal University of Technology. Minna. Niger State. Nigeria. *Email: ramatraji91@gmail.com.

\begin{abstract}
Caves are natural aperture and oligotrophic extreme environment for psychrophilic and psychrotolerant microorganisms. Microorganisms found in caves can be indigenous to the caves or introduced by humans, animals, water flow and wind action. Group of microorganisms found in caves are bacteria, fungi, protozoa, algae and viruses. However, bacteria and fungi are the dominant microorganisms. Cave microorganisms are metabolically diverse and are able to acquire energy independently through photoautotrophic, chemoautotrophic or heterotrophic activities. Different microbial groups also interact in the formation of cave and as part of the biogeochemical cycling of elements. Cave microbiology has allowed the detection of microorganisms with the potentials to produce different biomolecules for industrial, pharmaceutical, environmental and biotechnological purposes.
\end{abstract}

Keywords: Cave; Psychrotrophic microorganisms; Psychrotolerant microorganisms; Biogeochemical cycling.
Received

August 7, 2019

Accepted

December 15, 2019

Released

December 31, 2019

Full Text Article

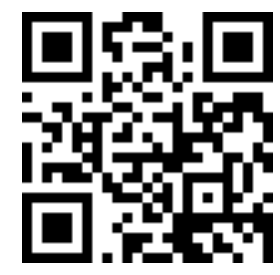

ORCID

(D) 0000-0001-8872-3884

Ramat Onyeneoyiza

Raji

(D) 0000-0001-9470-8488

Oluwafemi Adebayo Oyewole

D 0000-0002-0584-323X

Omeiza Haruna

Ibrahim

D) 0000-0003-4163-9209

Yetunde Noimot Tijani

(1) 0000-0003-3097-7130

Mordecai Gana 


\section{Introduction}

Caves are oligotrophic, dark ecosystems providing extreme conditions (relatively constant low temperature and high relative humidity), for psychrophilic and psychrotolerant microorganisms that are able to grow in the environment (Wiseschart et al., 2018). Tomczyk-Żak and Zielenkiewicz (2016) reported that the limestone Kartchner cave has a humidity of $99.4 \%$, temperature of $19.8{ }^{\circ} \mathrm{C}$ and a $\mathrm{CO}_{2}$ concentration from 1.000 to $5.000 \mathrm{ppm}$. These specialized microorganisms called extremophiles, produce enzymes that are functional under extreme conditions which is an essential mechanism for adaptation by microorganisms to cold environments (Tomova et al., 2013).

The world largest cave, Son Doong Cave, Vietnam, discovered in 2009, measures up to $5 \mathrm{~km}$ in length, with sections of about $200 \mathrm{~m}$ high and $150 \mathrm{~m}$ wide. The deepest cave, Krubera Cave, Georgia, near the Black Sea, was discovered in 2001 and extends to a depth of 2,191 $\mathrm{m}$ into the subsurface. Qaqa Mach'ay Cave is the highest cave known, and was discovered in Peru in 2004 at an altitude of nearly 5,000 m. Due to natural karstification as well as continued exploration, Mammoth Cave is now estimated to cover a distance of around $600 \mathrm{~km}$, and as such represents the longest cave known on Earth (Lee et al., 2012).

Different groups of microorganisms such as bacteria, archaea, viruses and fungi are found in caves. However, increased human access and cave alterations for tourism purposes (pavements and lighting systems' installation) can alter the natural microbial population, introduce new microorganisms and change the caves' microclimatic conditions. These changes can result in threat to cave features such as Palaeolithic paintings and finger flutings over time (Shapiro and Pringle, 2010; Saiz-Jimenez, 2012).

\section{Microbial diversity in caves}

Different caves have different groups of microorganisms occupying varying ecological niches. Microorganisms found in caves can be indigenous to the caves or introduced by humans, animals, water flow and wind action (Adetutu and Ball, 2014). The occurrence and structure of microbial communities is influenced by factors such as $\mathrm{pH}$, availability of nutrients, light, oxygen, sulfur and compounds of other metals, humidity, and susceptibility of the substrate to colonization. Alteration of physico-chemical conditions can also influence a change in species composition (Engel et al., 2010; Jones and Bennett, 2014). Cave is made up of several groups of organisms which include bacteria, fungi, viruses, algae and protozoa.

\section{Bacteria in caves}

Caves contain a broad variety of bacteria belonging to the Proteobacteria, Firmicutes, Nitrospirae, Actinobacteria and Acidobacteria. Zhou et al. (2007) reported that Proteobacteria is the largest group, followed by Acidobacteria, Actinobacteria, and Firmicutes, when the bacterial diversity in caves from Australia, China, Spain and USA were compared. Ikner et al. (2007) suggested that the abundance of proteobacteria in caves could be as a result of increased organic input by cave visitors. Wiseschart et al. (2018) reported that bacterial diversity analysis based on $16 \mathrm{~S}$ rRNA sequencing revealed that Actinobacteria is the largest taxonomic group classified into the order of Actinomycetales, Solirubrobacterales, Acidimicrobiales, Gaiellales, and Rubrobacterales. This is followed by Proteobacteria which is in the order of gamma Proteobacteria, alpha Proteobacteria, beta Proteobacteria, and delta Proteobacteria. Other phyla accounted only for small fraction in this community, namely, Acidobacteria, 
Gemmatimonadetes, Firmicutes, Bacteroidetes, Nitrospirae, Planctomycetes, Chloroflexi, and Verrucomicrobia in Manao-Pee Cave, Thailand.

Tomczyk-Żak and Zielenkiewicz (2016) reported that the Lower Kane Cave, rich in sulfur compounds at high concentration and small amounts of oxygen, is dominated by betaProteobacteria and the water flowing out of the cavern to the external environment, which contains large amounts of oxygen and low concentrations of sulfur, is dominated by gamma Proteobacteria. However, different caves have different groups of microorganisms occupying varying ecological niches and they can be indigenous to the caves or introduced by humans, animals, water flow and wind action (Adetutu and Ball, 2014). The bacteria isolated from several Siberian karsts have been identified as Pseudomonas sp, Bacillus sp., Arthrobacter sp, Nitrospira sp., Leptospirillum sp., Thermodesulfovibrio sp., Candidata sp., Magnetobacterium sp., and Magnetoovum sp. Most of the isolated Actinobacteria is assigned to the genus Streptomyces in certain caves such as Grotta dei Cervi (Italy), Altamira and Tito Bustillo (Spain), and 19 karstic caves in Turkey (Kunisawa, 2010; Yucel and Yamac, 2010; Wiseschart et al., 2018). Other species include Enterobacter asburiae, Pseudomonas putida, P. fluorescens, P. plecoglossicida, Micrococcus luteus, Bacillus flexus, B. safensis, B. amyloliquefacien, Serretia sp., Acinetobacter sp., Stenotrophomonas sp., Sphingobacterium sp., Acinetobacter and Comamonas sp (Wiseschart et al., 2018).

\section{Fungi in caves}

Fungi are important group of organisms found in caves colonizing different substrates and usually form complex microbial consortium with other microorganisms. Mulec et al. (2012) identified Penicillium sp. and Aspergillus sp. among diverse bacterial biota in microbial mat covering rocky surface and fungus belonging to Cladosporium herbarum group in weathered limestone. Over 500 genera of fungi, slime moulds and fungus-like taxa have been reported in caves worldwide. These belong to different taxa such as Ascomycota, Basidiomycota, Zygomycota, Mycetozoa, Oomycota and Chytridiomycota (Vanderwolf et al., 2013).

Ascomycota appears to be the most dominant group (Adetutu et al., 2011; Gherman et al., 2014). Commonly isolated species include Aspergillus fumigates, A. versicolor, A. niger, A. ustus, A.flavus, Fusarium solani, Nocardia altamirensis, Geotrichum sp., Penicillium chrysogenum, P. brevicompactum, P. simplicissimum, Mucor sp., Fusarium solani, Mortierella sp., Geomyces pannorum, Trichoderma viride, Beauveria bassiana, Cephalotrichum stemonitis, Cladosporium herbarum, Alternaria alternata, Aureobasidium pullulans, Paecilomyces lilacinus, Rhizopus stolonifer and Cladosporium cladosporioides. In terms of pathogens, Histoplasma capsulatum (causes histoplasmosis in cavers) and Pseudogymoascus destructans, which was formerly known as Geomyces destructans (causes the devastating white nose disease in bats) are famous examples although other opportunistic pathogens such as Trichosporon spp. (Basidiomycota) and Microsporum gypseum (dermatophytes) are known (Jurado et al., 2010; Minnis and Lindner, 2013; Vanderwolf et al., 2013).

\section{Protozoa in caves}

These are unicellular eukaryotic organisms like amoeba, sporozoans and flagellates. They are present in large numbers yet little has been studied in caves. Some probably live in cave and others are washed in. Amoebae and other protozoans are an integral part of all ecosystems. Their dynamics and community structure is an important indicator of biotic and abiotic changes in 
the environment. Mulec and Walochnik (2007) isolated from a cave pool with calcite rafts in Pečina Borštu cave the potentially pathogenic Acanthamoeba castellanii and Hartmannella vermiformis. Both amoebae can serve as vectors for intracellular pathogenic bacteria. Echinamoeba silvestris is identified in the vicinity of speleothems in the epilithic algal community. These amoebae are known to occur at extreme environments, though they are regarded as non pathogenic (Walochnik and Mulec, 2015). They are all chemoheterotrophs. Some are parasitic on cave vertebrates and invertebrates, while others are free living on organic matter, bacteria and other protozoa. They in turn serve as food for other cave biota.

\section{Algae in caves}

Cyanobacteria and algae are the component of the cave microflora. Among the identified groups, Chlorophyta is the largest group while Dinophyta formed the smallest group. Bracteacoccus minor (Chlorophyta), Nodularia harveyana (Cyanobacteria), Tetracystis intermedia (Chlorophyta), are found in Caves of the Polish Jura (South Poland). Some free living algae are found deep in caves and some have an absence of chlorophyll. These algae use non photosynthetic metabolic pathways to survive without light. Many species exists in the soil. Organic matter in water can be used as substitute for photosynthesis by algae (CzerwikMarcinkowska and Mrozińska, 2011).

\section{Archaea in caves}

Archaea are also found in caves (although in lesser numbers) with members of the Euryarchaeota, Crenarchaeota, Thaumarchaeota, Korachaeota, and Nanoarchaeota being detected. Either Euryarchaeota or Crenarchaeota appear to be the most dominant phyla in molecular assay results (Legatzki et al., 2011). Groups mostly found include the methanogens, which produce methane. Some members of the Euryarchaeota and Crenarchaeota groups (Archaea) are heterotrophs while others are thought to be chemolithotrophs involved in the formation of iron and manganese oxides in mineral rich caves (Northup et al., 2003).

\section{Viruses in caves}

Viruses are also found in caves and have become important given the outbreak of Ebola virus in some parts of the world. Most cave viruses of health concern are borne by bats (as reservoir hosts) from which these viruses can spread to cave visitors (animals and humans). Fruit bats are natural hosts of Marburg viruses (deadly hemorrhagic fever) while some African bats are hosts of the lethal Ebola virus with no known cure. Bat guano is rich in other viruses such as Adenoviruses, Astroviruses and herpesviruses (Li et al., 2010). Many prokaryotes in various types of extreme ecosystems are in general attacked by viruses. Several infectious viruses have been reported from caves, in particular from animals like insects or mammals residing in caves. These animals may themselves be attacked by viruses, such as the West Nile virus, or alternatively serve as significant reservoirs of viruses that infect humans and other animals, e.g. emerging zoonotic viruses, such as lassaviruses, filoviruses and paramyxoviruses (Quan et al., 2010; Lee et al., 2012).

\section{Microbial activities in caves}

Environmental factors such as $\mathrm{CO}_{2}$, temperature and organic matter content influence caves' microbial activities. Different ecological roles have been detected among various cave microorganisms, and between microorganisms and the environment, which includes; biogeochemical cycling of nutrients, Antagonism, Saprophytism, Cave formation and Parasitism.

$$
\text { Trichoderma sp. and }
$$

Pseudomonas sp. show antagonistic effect 
on actinomyces and Cladosprium respectively. Poor levels of nutrients in the caves promote the competition among microorganisms by production of high amounts of exopolymeric substances, enzymes and antimicrobial metabolites that is one of the strategies for their survival. Actinobacteria isolated from cave soils in Korea have been antagonistic to plant pathogenic fungi (Palaniyandi et al., 2013). Some Actinobacteria (Mycobacterium and Streptomyces) and fungi help in organic compound decomposition. Other genera include Rhodococcus, Gordonibacter and Corynebacterium. They are also involved in carbon cycling. They help in plant biomass decomposition in conjunction with fungi and other organisms like Nocardia, Micromonospora and cellulomonas. They convert organic carbon compounds into their simple form, releasing $\mathrm{CO}_{2}$. Cave fungi such as Fusarium and Cladosporium can function as decomposers of dead cave insects, fauna, animal, droppings and extraneous organic matter (Jurado et al., 2008; Adetutu et al., 2011).

Some microorganisms are sources of food to cave invertebrates, protozoa and insect. Others may live inside the insect digestive system, both enabling the cave insect to survive in an environment where food is scarce. Some protozoa also feed on several species of bacteria in caves (Huber et al., 2014). In association with the cave cricket (Troglophilus neglectus), Mucor troglophilus was regularly found on living T. neglectus adults and on larvae. Troglophilic moths, Scoliopteryx libatrix and Triphosa dubitata are frequently infected with entomopathogenic fungi. Life and dead imagos of troglophilic moths, S. libatrix and T. dubitata harbor entomopathogenic fungi (Tkavc, 2007). Microorganisms have been found in association with carbonate and silicate speleothems, sulfur compounds, iron and manganese oxides, and saltpeter. Ironoxidizing bacteria have also been identified from cave sediments, cave walls, and karst aquifers, and recent studies have shown that deposits of ferromanganese minerals do accumulate and change due to microbial activities. Several of these microorganisms are adapted to oligitrophic environment and use biological cycles based not only on carbon, but also on nitrogen or sulphur. Some can even live on rocks only (chemolithoautotrophs). Some of these species also deliver new chemical substances that can have antimycotic or antibiotic activity, and may lead to the development of new medicines (Tomczyk-Żak and Zielenkiewicz, 2016).

\section{Cave formation/Modification}

Microorganisms play an important role in the formation of caves by interacting with minerals, forming structures such as stalactites, stalagmites, as well as in decay of rocks (accumulation of metal oxides as a result of microbial activity, causing formation of brittle rock surface), which lead to cave expansions. Microorganisms are able to colonize bare rock surfaces, utilize the little organic nutrient in dripping waters and interfere in mineral crystallization processes. Some microorganisms precipitate $\mathrm{CaCO}_{3}$ on the surface of their cells, which contributes to formation of limestone(Laiz et al., 2003; Tomczyk-Żak and Zielenkiewicz, 2016).

Microorganisms cause the dissolution of cave features through acidic metabolic by-products. In caves, a variety of precipitation and dissolution processes results in the deposition of carbonate speleothems, silicates, iron and manganese oxides, sulfur compounds, and nitrates, and the breakdown of limestone walls. Dissolution of mineral surfaces occur through mechanical attack, secretion of exoenzymes, organic and mineral acids, and a variety of other mechanisms. These microbially mediated reactions generate considerable acidity that can dissolve cave walls or speleothems. Sulfuric aciddriven speleogenesis, where sulfuric acid 
causes the dissolution of limestone and results in the precipitation of gypsum. For example, Thiobacillus bacteria gain energy from the oxidation of sulfur or sulfide to sulfuric acid and can contribute to dissolution of carbonate bedrock in caves (Northup et al., 2000; Engel et al., 2004).

\section{Conclusion}

Cave offers promising prospects. It has been found to be source of novel microorganisms and bimolecules such as enzymes and antibiotics that may be suitable for biotechnological purposes.

\section{Conflict of interests}

Authors declare that there are no conflicts of interest.

\section{References}

Adetutu, E. M.; Ball, A. S. Microbial diversity and activity in caves. Microbiology Australia, v. 35, no. 4, p. 192-194, 2014. https://doi.org/10.1071/MA14062

Adetutu, E. M.; Thorpe, K.; Bourne, S.; Cao, X.; Shahsavari, E.; Kirby, G.; Ball, A. S. Phylogenetic diversity of fungal communities in areas accessible and not accessible to tourists in Naracoorte Caves. Mycologia, v. 103, no. $5, \quad$ p. $959-968,2011$. https://doi.org/10.3852/10-256

Czerwik-Marcinkowska, J; Mrozińska, T. Algae and cyanobacteria in caves of the Polish Jura. Polish Botanical Journal, v. 56, no. 2, p. 203-243, 2011.

Engel, A. S.; Meisinger, D. B.; Porter, M. L.; Payn, R. A.; Schmid, M.; Stern, L. A.; Lee, N. M. Linking phylogenetic and functional diversity to nutrient spiraling in microbial mats from Lower Kane Cave (USA). The ISME Journal, v. 4, no. 1, p. 98-110, 2010. https://doi.org/ 10.1038/ismej.2009.91

Engel, A. S.; Stern, L. A.; Bennett, P. C. Microbial contributions to cave formation: New insights into sulfuric acid speleogenesis. Geology, v. 32, no. 5, p. 369-372, 2004. https://doi.org/10.1130/G20288.1
Gherman, V. D.; Boboescu, I. Z.; Pap, B.; Kondorosi, E.; Gherman, G.; Maroti, G. An acidophilic bacterial-archaeal-fungal ecosystem linked to formation of ferruginous crusts and stalactites. Geomicrobiology Journal, v. 31, no. 5, p. 407-418, 2014. https://doi.org/10.1080/01490451.2013.83 6580

Huber, K. J.; Wüst, P. K.; Rohde, M.; Overmann, J.; Foesel, B. U. Aridibacter famidurans gen. nov., sp. nov. and Aridibacter kavangonensis sp. nov., two novel members of subdivision 4 of the Acidobacteria isolated from semiarid savannah soil. International Journal of Systematic and Evolutionary Microbiology, v. 64, no. 6, p. 1866-1875, 2014. https://doi.org/10.1099/ijs.0.060236-0

Ikner, L. A.; Toomey, R. S.; Nolan, G.; Neilson, J. W.; Pryor, B. M.; Maier, R. M. Culturable microbial diversity and the impact of tourism in Kartchner Caverns, Arizona. Microbial Ecology, v. 53, no. 1, p. 30-42, 2007. https://doi.org/10.1007/s00248-006-9135-8

Jones, A. A.; Bennett, P. C. Mineral microniches control the diversity of subsurface microbial populations. Geomicrobiology Journal, v. 31, no. 3, p. 246-261, 2014. https://doi.org/10.1080/ 01490451.2013.809174

Jurado, V.; Boiron, P.; Kroppenstedt, R. M.; Laurent, F.; Couble, A.; Laiz, L.; Bergeron, E. Nocardia altamirensis sp. nov., isolated from Altamira Cave, Cantabria, Spain. International Journal of Systematic and Evolutionary Microbiology, v. 58, no. 9, p. 2210-2214, 2008. https://doi.org/ 10.1099/ijs.0.65482-0

Jurado, V.; Laiz, L.; Rodriguez-Nava, V.; Boiron, P.; Hermosin, B.; Sanchez-Moral, S.; Saiz-Jimenez, C. Pathogenic and opportunistic microorganisms in caves. International Journal of Speleology, v. 39, p.15-21, 2010. https://doi.org/10.5038/1827-806X.39.1.2

Kunisawa, T. Evaluation of the phylogenetic position of the sulfate-reducing bacterium Thermodesulfovibrio yellowstonii (Phylum Nitrospirae) by means of gene order data from completely sequenced genomes. International Journal of Systemic and Evolutionary Microbiology, v. 60, no. 5, p.1090-1102, 2010. https://doi.org/ 10.1099/ijs.0.014266-0 
Lee, N. M.; Meisinger, D. B.; Aubrecht, R.; Kovacik, L.; Saiz-Jimenez, C.; Baskar, S.; Baskar, R.; Liebl, W.; Porter, M. L.; Engel, A. S. Caves and karst environments. In: Bell, E. M. (Ed.). Life at extremes: Environment, organisms, and strategies for survival. Cambridge: CAB International, 2012. p. 320344.

Legatzki, A.; Orttiz, M.; Neilson, J. W.; Dominguez, S.; Andersen, G. L.; Toomey, R. S.; Maier, R. M. Bacterial and archaeal community structure of two adjacent calcite speleothems in Kartchner Caverns, Arizona, USA. Geomicrobiology Journal, v. 28, no. 2, p. 99-117, 2011. https://doi.org/10.1080/ 01490451003738465

Li, L.; Victoria, J. G.; Wang, C.; Jones, M.; Fellers, G. M.; Kunz, T. H.; Delwart, E. Bat guano virome: Predominance of dietary viruses from insects and plants plus novel mammalian viruses. Journal of Virology, v. 84, no. 14 , p.6955-6965, 2010. https://doi.org/10.1128/JVI.00501-10

Minnis, A. M.; Lindner, D. L. Phylogenetic evaluation of Geomyces and allies reveals no close relatives of Pseudogymnoascus destructans, comb. nov., in bat hibernacula of Eastern North America. Fungal Biology, v. 117, no. 9, p. 638-649, 2013. https://doi.org/10.1016/j.funbio.2013.07.00 1

Mulec, J.; Walochnik, J. Amoeba in carbonate precipitating microenvironments in karst caves. Geophysical Research Abstracts, v. 9, 2007.

Mulec, J.; Krištůfek, V.; Chroňáková, A. Comparative microbial sampling from eutrophic caves in Slovenia and Slovakia using RIDA $®$ COUNT test kits. International Journal of Speleology, v. 41, no. 1, p. 1-8, 2012 . https://doi.org/10.5038/1827806X.41.1.1

Northup, D. E.; Barns, S. M.; Yu, L. E.; Spilde, M. N.; Schelble, R. T.; Dano, K. E.; Dahm, C. N. Diverse microbial communities inhabiting ferromanganese deposits in Lechuguilla and Spider Caves. Environmental Microbiology, v. 5, no. $11, \quad$ p. 1071-1086, 2003. https://doi.org/10.1046/j.1462-2920. 2003.00500.x

Northup, D. E.; Dahm, C. N.; Melim, L. A.; Spilde, M. N.; Crossey, L. J.; Lavoie, K. H.; Mallory, L. M.; Boston, P. J.; Cunningham, K. I.;
Barns, S. M. Evidence for geomicrobiological interactions in Guadalupe caves. Journal of Cave and Karst Studies, v. 62, no. 2, p. 8090, 2000.

Palaniyandi, S. A.; Yang, S. H.; Zhang, L.; Suh, J. W. Effects of actinobacteria on plant disease suppression and growth promotion. Applied Microbiology and Biotechnology, v. 97, no. 22, p. 9621-9636, 2013. https://doi.org/ 10.1007/s00253-013-5206-1

Quan, P. L.; Firth, C.; Street, C.; Henriquez, J. A.; Petrosov, A.; Tashmukhamedova, A.; Hutchison, S. K.; Egholm, M.; Osinubi, M. O.; Niezgoda, M.; Ogunkoya, A. B.; Briese, T.; Rupprecht, C. E.; Lipkin, W. I. Identification of a severe acute respiratory syndrome coronavirus-like virus in a leaf-nosed bat in Nigeria. mBio, v. 1, no.4, e00208-10, 2010. http://doi.org/10.1128/mBio.00208-10

Saiz-Jimenez, C. Microbiological and environmental issues in show caves. World Journal of Microbiology and Biotechnology, v. 28, no. 7, p. 2453-2464, 2012. https://doi.org/10.1007/s11274-0121070-x

Shapiro, J.; Pringle, A. Anthropogenic influences on the diversity of fungi isolated from caves in Kentucky and Tennessee. The American Midland Naturalist, v. 163, no. 1, p. 76-86, 2010. https://doi.org/10.1674/ 0003-0031-163.1.76

Tkavc, R. Identification and genotypization of entomopathogenic fungi isolated from troglophile moths Scoliopteryx libatrix L. and Triphosa dubitata L. Ljubljana: University of Ljubljana, Biotechnical Faculty, 2007. (Graduation theseis).

Tomczyk-Żak, K.; Zielenkiewicz, U. Microbial diversity in caves. Geomicrobiology Journal, v. 33, no. 1, p. 20-38, 2016. https://doi.org/10.1080/01490451.2014.10 03341

Tomova, I.; Lazarkevich, I.; Tomova, A.; Kambourova, M.; Vasileva-Tonkova, E. Diversity and biosynthetic potential of culturable aerobic heterotrophic bacteria isolated from Magura Cave, Bulgaria. International Journal of Speleology, v. 42, no. 1 , p. $65-76$, 2013. https://doi.org/ 10.5038/1827-806X.42.1.8

Vanderwolf, K. J.; Malloch, D.; McAlpine, D. F.; Forbes, G. J. A world review of fungi, yeasts, and slime molds in caves. International 
Journal of Speleology, v. 42, no. 1, p. 77-96, 2013. https://doi.org/10.5038/1827-806X. 42.1 .9

Walochnik, J.; Mulec, J. Free living amoebae in carbonate precipitating microhabitats of karst caves and a new vahlkampfiid amoeba, Allovahlkampfia spelaea gen. nov. Acta Protozoologica, v. 48, no. 1, p. 25-33, 2015.

Wiseschart, A.; Mhuanthong, W.; Thongkam, P.; Tangphatsornruang, S.; Chantasingh, D.; Pootanakit, K. Bacterial diversity and phylogenetic analysis of type II polyketide synthase gene from Manao-Pee Cave. Geomicrobiology Journal, v. 35, no. 6, p. 518-527, 2018. https://doi.org/10.1080/ 01490451.2017.1411993

Yucel, S. E.; Yamac, M. U. Selection of Streptomyces isolates from Turkish Karstic caves against antibiotic resistant microorganisms. Pakistan Journal of Pharmaceutical Sciences, v. 23, no. 1, p. 1-6, 2010.

Zhou, J. P.; Gu, Y. Q.; Zou, C. S.; Mo, M. H. Phylogenetic diversity of bacteria in an earthcave in Guizhou Province, Southwest of China. Journal of Microbiology, v. 45, no. 2, p. 105-112, 2007.

License information: This is an open-access article distributed under the terms of the Creative Commons Attribution License, which permits unrestricted use, distribution, and reproduction in any medium, provided the original work is properly cited. 